\title{
ARTIGOS
}

\section{POLITICAL PHILOSOPHY, ETHNOLOGY, AND TIME: A STUDY OF THE NOTION OF HISTORICAL HANDICAP}

João Feres $J r^{*}$

\begin{abstract}
This article starts by identifying the crucial importance of the notion of historical handicap for the present-day social sciences of Latin America. Such notion is not an original invention made by Latinamericanists. On the contrary, I demonstrate that the genealogy of the notion of historical handicap must be sought in the tradition of Western political philosophy. Such genealogy must take into account the way it was integrated into ethnological descriptions. When and how did the Other become the backward, the primitive? While this relation was secondary for ancient Greek thought, theories of historical development became the main source of ethnological categories in the modern era. Interestingly enough, this modern synthesis suited the practical purpose of justifying two successive waves of European imperialistic: the era of discoveries, and $19^{\text {th }}$ century colonialism. The article concludes by raising questions about the present role and application of the social sciences.
\end{abstract}

RESUMO Esse artigo começa por identificar o papel central da noção de incapacidade histórica para a literatura de Latin American studies produzida no pós-guerra. Tal noção não foi criada pelos Latinoamericanistas contemporâneos. É possivel identificar o embrião da noção de incapacidade histórica nos mitos primitivistas da antiguidade clássica e, a partir daí, exa-

* Political Science Department - City University of New York - Graduate Center.

KRITERION, Belo Horizonte, $n^{0}$ 105, Jun/2002, p.19-42 
minar as várias maneiras com que ela foi recebida e rearticulada pela tradição filosófica ocidental. Esse estudo é feito tendo em vista a incorporação da noção de incapacidade histórica a teorias etnológicas. Quando e como o "outro" passou a ser visto como o "atrasado", o "primitivo"? Se na antiguidade clássica essa identificação era incompleta, na era moderna teorias de desenvolvimento histórico se tornaram a fonte principal de categorias etnológicas. É importante notar que a síntese moderna dessas teorias também serviram para justificar as aventuras imperialistas Européias: a era dos descobrimentos, e o colonialismo do século XIX. $O$ artigo termina apontando para a necessidade de um exame crítico dos propósitos e aplicações do conhecimento produzido pelas ciências sociais do presente.

\section{Introduction}

Positivist social sciences have been the target of severe criticism throughout the $20^{\text {th }}$ century. Its most vocal opponents come from German and French philosophical circles. Among those critics one can count the Frankfurt School's first generation (Adorno, Horkheimer, and Marcuse), its second generation (Habermas), hermeneutics (particularly Gadamer), Foucault, Lyotard, and many others. Roughly speaking, German critics rejected what they saw as an attempt of positivist social scientists to get rid of the activity of critical reflection and reduce reason to mere instrumentality. In Kantian terms, the positivist approach commits the sin of treating people solely as means - a problem that in the language of contemporary philosophy could also be understood as an act of misrecognition. From a Marxian/Hegelian point of view, treating human affairs in terms of absolute certainty restricts man's capacity to take hold of his own destiny. Instead of frontally opposing positivism, French critics tried to dismount the scientific claim to absolute certainty through a critique of the Enlightenment's conception of the unity of reason and its purely theoretical character.

This article is inspired by both critical traditions exposed above. Nevertheless, it does not strictly follows either one. The aim here is much more limited and humble. By tracing the genealogy of the notion of historical handicap, I intend to contribute to a critique of a particular field of contemporary social sciences practiced mostly in the United States: Latin America studies. This preliminary work exposes a facet of Latin America studies that is usually hidden for most of the people who consume its texts and theories. By examining the writings of past authors, I intend to demonstrate that the notion of historical handicap, which has been crucial for the social scientific charac- 
terization of Latin America, has in fact deep roots in the Western philosophical tradition. Ironically enough, we will find that in the past this notion was connected with the justification of colonialist and imperialist practices something that according to the present Western moral standards have become unacceptable. Does Latin America studies justify the same practices? That is a question that Brazilians should try to answer. After all, they are not only consumers of the Latin America studies literature produced in the United States, but also part of the object of study of that same literature. Brazilians should understand what it means to be Latin American for that particular literature because, after all, they have been treated as such for quite a long time.

In section 1 of this article I will briefly demonstrate the importance of the notion of historical handicap as a basic ethnological tool for Latin America studies. Section 2 starts with the exam of a quintessential example of the application of "historical handicap": Hegel's account on the unhistorical character of Oriental history. From Hegel, I go back in section 3 to Aristotle's proto-Orientalism and its connections with his conception of time and primitivism (an early form of historical handicap). In the same section, I analyze the ancient notions of primitivism to argue that Aristotle's conception of primitivism is not clearly connected with his justification for the Greek colonization of Persians. In section 4, I discuss how conceptions of historical time changed from antiquity to modernity, giving a particular emphasis to the transformations brought about by the rise of Christianity. Augustine and Aquinas's ideas on history and slavery are analyzed in section 5. In the same section, I examine the reception of Aquinas's theory of slavery by some $16^{\text {th }}$ century Spanish theologians. As I intend to show, those authors were the first to fully transform the notion of historical handicap into a universal ethnological tool. Finally, section 6 addresses the contribution of the Enlightenment's philosophes to the perfection of the idea of historical handicap.

\section{1}

The "underdevelopment" of Latin America has been one of the main topics of the Latin America studies literature. Since the consolidation of the profession of Latin American specialist, after World War II, entire libraries have been written on this subject. For dealing with this problem, Latin Americanists produced ethnological accounts that aimed at explaining Latin America's underdevelopment as a first step in the quest for solutions that would promote development. More specifically, Latin America's alleged un- 
derdevelopment was quite often understood as a product of its ultimate incapacity to have historical 'progress', that is, of its historical handicap.

For example, Seymour M. Lipset, an influential representative of modernization theory, finds that the values that govern Latin American behavior are "ascription, particularism, diffuseness, and elitism." According to Lipset, this is due to the strong heritage of Iberian culture that keeps the entire region in a semi-feudal state. ${ }^{1}$ For Lipset, Latin Americans are tied to their past, and thus incapable of transforming themselves. He concludes that the only agents who can bring development to Latin America are foreign capitalists and European immigrants (Lipset and Solari 1967).

Thirty years after Lipset reported his 'discoveries', Glen Caudill Dealy writes that "the civic virtues cherished by Latin Americans are essentially those perfections prized by classic Roman civilization...many virtues and values have changed little over the centuries" (Dealy 1996). In sum, for this author, the stagnation of the Latin spirit is even older than Lipset had imagined.

The theme of historical incapacity permeates the vocabulary used to 'describe' Latin America. For example, Christian Smith declares that "Latin America's half-millennium old dominant political culture of 'monistic corporatism' ... is grounded in the pre-Enlightenment, prescientific-revolution, precapitalist, aristocratic, patrimonial, monolithically Catholic, and structurally semifeudal world of the Iberian Peninsula of the sixteenth century" (Smith 1994). Reinforcing the theme of Latin American historical immobility, Howard Wiarda writes "we need to know the roots and background of Latin America, why the weight of history and the past remains so heavy there ... We must therefore study not just Latin America's recent politics but its origins in medieval Iberia and in the system Spain and Portugal transferred to the New World" (Wiarda 1990).

In sum, the notion of historical handicap is a pervasive rhetorical tool for describing Latin America as a place that is not only spatially separated from the speaker (Latin American specialist) but also temporally distinct - an object immersed in the past. Through this same operation, the American social scientist (the subject of knowledge) situates himself in a different place (the developed American academia), which is not hostage of its own history, and, therefore, fully exists in the present with an eye in the future.

In the following sections, I demonstrate that rather than being freshly invented by Latinamericanists, the notion of historical handicap is the pro-

1 The italics in the following passages are added to highlight words with temporal semantic load. 
duct of a long genealogy of ethnological concepts used mostly by Europeans to describe and evaluate the Other. ${ }^{2}$ Moreover, I show that such concepts were often used with the very practical purpose of justifying the subjection of the Other to Europeans.

2

No author has formulated the notion of historical handicap with more eloquence and force than Hegel. In the Philosophy of History he writes the following passage to comment on the Oriental Empires:

For outside the One Power - before which nothing can maintain an independent existence - there is only revolting caprice, which, beyond the limits of the central power, roves at will without purpose or result... On the one side we see duration, stability - Empires belonging to mere space, as it were [as distinguished from Time] - unhistorical History; - as for example, in China, the State based on the Family relation; a paternal Government, which holds together the constitution by its provident care, its admonitions, retributive or rather disciplinary inflictions; -a prosaic Empire, because the antithesis of Form, viz., Infinity, Ideality, has not yet asserted itself. On the other side, the Form of Time stands contrasted with this spatial stability. The States in question, without undergoing any change in themselves, or in the principle of their existence, are constantly changing their position towards each other. They are in ceaseless conflict, which brings on rapid destruction... This History, too is, for the most part, really unhistorical, for it is only the repetition of the same majestic ruin.

Hegel classifies different societies in the 'history of the world' by first asking "whether [the individuals'] actual life is an unreflecting use and habit combining them in this unity (the state), or whether its constituent individuals are reflective and personal beings hav[e] properly subjective and independent existence." Through the application of this criterion, Hegel concludes that History traveled from East to West - from its childhood in the Orient to its maturity in Germanic Europe. Despite being the first stage of the History of Spirit, the Orient stayed, according to him, eternally trapped in the "childhood of history," a condition in which only "One is Free" - in contrast with the condition achieved by the Teutonic people in which "All are free."

For Hegel, both India and China were incapable of having history, of progressing into something different from what they have always been: a despotic state. The subjective will of the Oriental is not rational (and thus not

2 The term "Other" is used here with capital " $O$ " to refer to the ones perceived to be other, the cnes that are seen as "not belonging". That is done to indicate that rather than a determinate group of people, the Other is constituted solely by the negation of a collective Self-image. 
free) but bound to the state by faith, "confidence, and obedience." In those societies, reason exists only in the objective organization of the state that revolves around the figure of the sovereign, the patriarch. In other words, the condition of the Oriental, according to his own will, is that of a subject. Violent disruption, usually caused by the invasion of barbaric hordes, might bring the ruin of the previous traditional order only to replace it with another despotic state. In other words, Orientals are incapable of truly transformative action; they are eternally trapped in an ahistorical space of sameness.

In Hegel's Philosophy of History one can find the association between Orient and despotism connected with the idea that Oriental societies are incapable of history. The quasi-descriptive style of Hegel's narrative in this book does not provide the readers with a tight causal explanation for this state of affairs. Coherently enough, the "fact" that Oriental societies are incapable of history is treated by the author as an observable datum, a given. Another important datum is the Orientals' willingness to be subjects of a despotic ruler. Hegel sometimes phrases the Oriental lack of free will in terms of knowledge: "The Orientals have not attained the knowledge that Spirit (Man as such) is free". Those "observations" are in fact connected: in Oriental societies there is no contradiction between the individual will and the state, thus the state is not only despotic, it will stay despotic for ever. At this point, one might be tempted to ask: but why is it so? What is the ultimate cause of this state of affairs?

Race does not seem to be a major factor. Hegel employs some racialist arguments in the Philosophy of History but mostly when speaking of "Negroes". In general terms, he defends that "the formation of races lie[s] beyond the limits of History" (Hegel 1899, 110). His adoption of the Hippocratean theory of climatological and geographical influence is explicit but limited. That is, Hegel thinks that those influences should be understood as barriers and limitations imposed to the development of Spirit rather then as the ultimate causes of its development (Hegel 1899, 79-80). In sum, in Hegel's text there seems to be no clear answer to the question of the causes of the Oriental ahistorical nature. For the philosopher, they simply are (were and have been) this way.

\section{3}

Hegel did not create the association between Orientals and despotism. In fact, this is an age-old topic in political philosophy that can be traced back to ancient Greece. Aristotle provides us with the most formidable version of this argument, in which he states that barbarians (and here he meant particularly 
Persians) were slaves by nature while Greeks were free by nature. ${ }^{3}$ For the philosopher, barbarians lacked the capacity to deliberate upon the course of action (phronesis) and therefore were not fitted for political life. The barbarians' defective reason allowed them to understand rational command but not to issue them. Consequently, Aristotle states that despotism is, by nature, the form of government that best suits barbarians - while Greeks should have a constitutional government (politeia) in which they both rule and are ruled.

The reason is that these barbarian peoples are more servile in character than Greeks; and they therefore tolerate despotic rule without any complaint (Aristotle 1958, 1285a).

Aristotle mirrors the political concept of barbaric despotism on his model of the household association: the despotic ruler governs his subjects like a master (despotes) rules over his slaves. Coherently enough, he classifies Oriental despotism among the forms of kingship, which is one of the "right constitutions". After all, a good form of government should be "to the advantage of cities and territories which are to be properly governed" (Aristotle 1958, $1284 \mathrm{~b}$ ). Since despotic rule is in agreement with the maxim of nature according to which the superior should always rule the inferior, Aristotle concludes that it is beneficial for both parts - the ruler and the ruled. ${ }^{4}$

Through the anthropological defense of the Asians natural inferiority, Aristotle could justify the naturalness of their submission to Greeks. According to Melvin Richter, Aristotle's argument of natural inferiority served a double purpose: 1) to justify the acquisition of non-Greek slaves by Greeks through war, and 2) to justify the submission of non-Greek cities to Greek despotic rulers (Richter 1990).

Despite their different vocabularies and style, Aristotle's and Hegel's depiction of Orientals have many common points. Both agree that despotism is the proper constitution for Orientals. Both identified Oriental societies with lack of freedom and incomplete rationality, while depicting their own societies as bastions of freedom and right reason. Even though Hegel avoids affirming that Orientals were servile by nature, he does characterize them as being

3 Although Aristotle became the most influential ancient source on despotism, the association between Persians and this form of government have circulated among Greeks at least since the wars between Persians and Greeks. For example, in Persians, a play produced for the Spring competition of $472 \mathrm{BC}$ in Athens, Aeschylus explicitly contrasts the despotic government of the Persians to Athenian democracy.

4 One might abject to Aristotle's argument by saying that since the ruler is also a barbarian, and thus, a slave by nature, the barbaric form of govemment should not be compared to the rule of the despotes over the household. A possible but not entirely satisfactory solution to the problem would be to argue that a truly despotic rule over barbarians only occurs when the monarch is Greek. Aristotle does advocate this type of rule. Furthermore, this was perfect justification for the Macedanian claims to legitimate rule in Asia. 
eternally stuck in a state of willing subjection. This might sound as a translation of Aristotle's "slave by nature" formula, but there is something more to it. Hegel interprets the Other, the Oriental, according to a theory of history, while Aristotle lacks that intellectual tool. Aristotle does not lean on arguments of historical retardation and primitivism in order to portray the inferiority of Asians. He prefers to see the Persians' rational capacity as incomplete rather than immature. ${ }^{5}$

In order to further explore Aristotle's position in relation to this issue we shall put his writings in context. Lets first examine some of his references to primitivism and, second, contrast it with definitions given by others authors of antiquity.

The idea of primitivism and its association with barbarism were not strange to Aristotle and his world.

Aristotle "writes":

\begin{abstract}
The most natural form of the village appears to be that of a colony or offshoot from a family; -and some have thus called the members of the village by the name of 'sucklings of the same milk', or, again, of 'sons and the sons of sons".... This, it may be noted, is the reason why each Greek polis was originally ruled-as the peoples of the barbarian world still are-by kings. They were formed of persons who were already monarchically governed... households are always monarchically governed by the eldest of the kin, just as villages, when they are offshoots from the household, are similarly governed in virtue of the kinship between their members (Aristotle 1958, 1252b).
\end{abstract}

While the reference to a generic connection between barbarism and kingship is clearly stated above, when discussing the forms of kingship, Aristotle points to a difference between the "primitive" constitutions of Greeks and the barbarians'.

Another type of kingship is the sort which is to be found among some uncivilized [i.e. non-Hellenic] peoples. Kingships of this sort all possess an authority similar to that of tyrannies; but they are, none the less, constitutional, and they descend from father to son ... Kingships among uncivilized peoples are thus of the nature of tyrannies; but, being constitutional and hereditary, they are at the same time stable... ... but there is also a third [type of monarchy], which used to exist among the ancient Greeks, and which goes by the name of dictatorship [Aisumniteia]. This may be roughly described as an elective form of tyranny. It differs from the type of kingship among uncivilized peoples, but only in being nonhereditary, and not in being nonconstitutional (Aristotle 1958, 1285a).

Even though Aristotle does not explain the causes of this difference, we

5 See the distinction between the rational capacities of slaves, women, and children in the Politics, 12596. 
should notice that in the passage above there is no perfect correspondence between barbarism and primitivism. The similarity between their forms of government is rather technical and approximate. In fact, the term barbarian (barbaros) was used by ancient Greeks to refer to all non-Hellenic peoples. Despite the generic nature of the term, Aristotle (as many other Greeks) does recognize differences among barbarians.

The peoples of cold countries generally, and particularly those of Europe, are full of spirit, but deficient in skill and intelligence; and this is why they continue to remain comparatively free, but attain no political development and show no capacity for governing others. The peoples of Asia are endowed with skill and intelligence, but are deficient in spirit; and this is why they continue to be peoples of subjects and slaves (Aristotle 1958, 1285a).

Based on the passage above we can conclude that not all barbarians are slaves by nature. On the contrary, the "Europeans" (most certainly a reference to the Scythians) were "comparatively free" and "full of spirit". Only the Asians were in fact "peoples of subjects and slaves". For Aristotle, it is the Europeans that better approximate the image of the primitive Greeks and not the Persians. Considering the problem in the light of Aristotle's teleological notion of nature, we can hypothesize that, for him, the Greeks of the past were free by nature but not yet developed - like the contemporary European barbarians. That is, in the case of the "ancient" Greeks, the simplicity of their way of life and social organization (but not nature) did not allow for a full political life. ${ }^{6}$

The fact that Aristotle refuses to identify the Persians with primitivism seems only reasonable for a philosopher that strived to be so. After all, despite the political differences between Greeks and Persians, the latter had a rich and sophisticated urban society that could hardly be identified with primitivism, even by their Greek foes. ${ }^{7}$ Like present-day notions of primitivism, the Greeks' was also linked to the idea of simplicity. If we put Aristotle's writings in context, we find that the thinkers of his time, as well as many generations of Greeks and Roman authors after him, usually referred to a particular people as a model of primitivism and simplicity: the Scythians.

Homer praises the Scythians' noble character. ${ }^{8}$ Aeschylus follows him, calling them "the most righteous of all men". ${ }^{9}$ Other ancient authors contri-

6 Aristotle also relies on the Hippocratic theory of geographical and climatic influence to explain the lack of European development. The cause was the extreme cold weather. Nonetheless, for Aristotle, those extemal environmental factors camnot be said to be given by nature.

7 See for example Socrates description of the wealth, splendor and luxury of Persian society in Plato's Alcibiades, $122 \mathrm{~b}-\mathrm{c}$.

I7iad, XIII, 1-6.

9 Fragm. 196. 
buted to immortalizing the association between Scythians and primitive virtue, among them, Strabo, Pseudo-Anacharsis, Cicero, Horace, and Virgil. According to Lovejoy and Boas, long before the Amerindians, the Scythians were the first people to be identified with the myth of the noble savage. Nonetheless, this myth does not fit well the modern notion of historical handicap because it conceives of history as a path toward degeneration. For its adepts, the urban life of the classical cities was to be blamed for man's loss of the simple virtues of primitive life (Lovejoy and Boas 1935).

In sum, the idea of primitivism in antiquity seems to have been dissociated from proto-Orientalism, that is, from the derogatory depiction of Persians - which was a common staple of ancient Greek culture. While Greeks already had various myths of development and degeneration, theories of history were not the main anthropological tool they used for evaluating Asians. Furthermore, at least for Aristotle, the justification for conquering and colonizing Orientals was not based on their primitive character. In sum, Hegel's account differs from the classical Greek forms of anthropological differentiation in one crucial aspect: the notion that human difference should be primarily understood in terms of a theory of history. For Hegel, a substantive notion of historical time had become the main anthropological category. Now that the gap between Hegel's and Aristotle's anthropologies was established, we are entitled to ask: when did this shift from natural difference to historical difference was introduced?

\section{4}

According to Karl Löwith, the idea of universal secular history is a modern creation with both Christian and Classical elements. Löwith claims that for the ancient Greeks, history was bound to eternal recurrence - which reflected the immutable and rational order of the cosmos. Historical progress was indeed possible as a movement towards perfection. This is patent in the projects of social reform proposed by Plato or in the political advices provided by Aristotle. ${ }^{10}$ Nonetheless, for both authors, once the desirable end was achieved no further progress would ensue. From that point on, stability should be pursued and any minute change might start a process of decadence - the Greeks "knew" that sooner or later this decadence would certainly ensue (Löwith 1949). ${ }^{11}$

\footnotetext{
10 I am not suggesting here that Plato is a typical representative of Greek classical culture. It is noteworthy, however, the fact that despite being atypically classical in many aspects, this precursor of monotheism still retained a cyclical notion of history.

11 A very telling example of the sentiment of inevitable degeneration can be found in Plato's Republic 545e-
} 
Löwith's thesis about the classical conception of time might not be completely wrong but it certainly is an overstated generalization. As Lovejoy and Boas show, through a cornucopia of textual evidence, the Greeks had many different "theories" of time, which can be roughly classified according to two categories: degenerative and progressive myths. ${ }^{12}$ The myth of the Golden age is probably the most well known example of degenerative theory. Men were first created noble, strong, and virtuous, and, through successive ages or generations, declined into an inferior condition. The Promethean myth corresponds to the progressive archetype. According to it, men were born defenseless and helpless. Prometheus then stole the fire of knowledge (techniques) from Olympus and gave it to men, allowing them to prosper by intelligence and skill. ${ }^{13}$ In sum, contrary to Löwith's beliefs, while degenerative and progressive myths could be diversely coupled with an idea of repetition (which was usually limited to the last stage of the mythological narrative), eternal recurrence was not the only classical conception of time (Lovejoy and Boas 1935). On the other hand, Löwith seems to be correct in arguing that the idea of secular improvement, of a movement towards perfection, was originally classical-pagan and not Christian. Early Christians were in general too convinced of the eminence of the end of times to be bothered with theories of secular development.

Löwith argues that Judeo-Christianity broke the circularity of the classical conception of history and transformed it into a line with creation at its beginning and salvation at its finis and telos. According to this author, the Enlightenment's faith in scientific and rational achievement eventually replaced the idea of a soteriological history with a notion of continuous, cumulative, and infinite secular progress. In sum, Löwith provides the modern conception of history with its own genealogical narrative: first, there is the classical circular conception of time; second, Christians replace that conception with a linear teleological narrative, finally, the Christian soteriologic telos is erased by the Enlightenment's philosphes, allowing history to be exclusively conceived in terms of secular progress. Löwith's thesis belongs to the family of historical theories that portray modernity as a product of the secularization of religious conceptions. Max Weber's The Protestant Ethic and the Spirit of Capitalism is probably the most famous example of such theories.

546b: "It is hard for a city composed in this way to change, but everything that comes into being must decay. Not even a constitution such as this will last forever. It, too, must face dissolution."

12 Hesiod is certainly the most ancient and authoritative source on this myth. Plato also referred to it many times in his dialogues. See Cratylus 397e for the original myth and the famous passages in the Republic (415a, 416e, 419-422d) where Plato uses the myth as an allegory for his political project.

13 For a somewhat altered version of this myth see Plato's Protagoras. 
Nonetheless, there are reasons to doubt Löwith's account. Hans Blumenberg, for example, claims that the modern conception of progress could not have sprung from Christianity. On the contrary, the Christians' anxious yearning for salvation always led them to reject the importance of secular development. Blumenberg discredits the contribution of Christianity to the modern idea of progress and also downplays the importance of the Enlightenment's "invention" of linear infinite secular progress - two arguments that are crucial to Löwith. This double operation is done by reducing the modern conception of progress to the realization that scientific knowledge can be improved upon through future methodic observation. Blumenberg argues that such notion of progress are already present in preChristian antiquity, in the astronomy treatises composed by Hipparchus and Seneca (Blumenberg 1974).

Both Löwith's and Blumenberg's theses are tremendously insightful. Nonetheless, one does not have to engage in the endless debate about the exact definition of modernity and progress in order to survey past conceptions of time. It seems that a more reasonable interpretation lies somewhere between the claims made by those authors. If Lovejoy and Boas are correct in relation to the plurality of ancient myths of time, we can hypothesize that the rise of Christianity to hegemony in the late classical era might have contributed to the decline of those myths. The Christian doctrine relied too heavily on its soteriological conception of time to allow for the survival of competitive versions. In was only roughly a thousand years later, with the advent of the renaissance and the revival of the interest for ancient pagan literature that some of those myths were "discovered". The reintroduction of the narrative of the state of nature in political philosophy is a clear sign of this revival.

\section{5}

Once we have examined the different theories about the history of time conceptions, we must go back to our original subject, that is, assessing how those conceptions were used as and transformed into anthropological tools. In order to accomplish that, we should examine not only the changing conceptions of time themselves, but also the way in which human difference (otherness) was conceptualized. In the following analysis I will give a particular attention to the development of the Christian justification of slavery. As we will see below, it is out of the Christian reception (and partial rejection) of the Aristotelian theory of slavery prompted by the encounters of the New World "new" time-based anthropological tools were devised.

Augustine possesses a conception of time that is essentially early-Chris- 
tian. Augustine's universal history practically precludes secular development. In his account, secular history is divided into six periods, which follow each other in a sequence analogous to human development, from infancy to old age. For Augustine, only two empires are actually historically worthy: Asian Assyrians and European Romans (Augustine 1958). That is, the dichotomy East-West appears in his writings already enmeshed with an embryonic conception of historical evolution. Nevertheless, for him, the only true historical progress was the pilgrimage of the City of God towards its soteriological eschaton. Compared to that, the succession of empires, wars and revolutions of secular history has very little relevance. Profane happenings acquire meaning only through reference to their transcendent purpose (Augustine 1958).

The historical narrative presented by Augustine is not coupled with a theory of natural inequality. Quite the contrary, for him all men equally descend from Adam. Like most Christian authors before Aquinas, Augustine justifies civil slavery, as a form of terrestrial punishment for sin according to God's will, but does not adhere to the theory of natural slavery.

It was only with the introduction of Aristotle's texts in Europe in the $13^{\text {th }}$ century that the theory of natural slavery was revived. Thomas Aquinas tried to find a solution of compromise to the question of slavery that would harmonize Aristotle's ideas and Christian teaching. He reaffirmed the Christian maxim that all men descend from Adam and added that all men are rational, and thus, potentially capable of recognizing the true religion. For Aquinas, as for the Thomists of the Salamanca School who followed him, all men are human. The fact that some men expressly denied Christianity, such as Saracens and Jews, is not a sign of their inhumanity but of sin, which, following Augustine's teaching, could be punished with legal enslavement.

Despite his opinion on human nature, Aquinas does not deny the existence of not fully rational quasi-human creatures. From Aquinas's Christian point of view, Aristotle's opinions on slavery were a source of equivocation: the Philosopher had affirmed that the slave was indeed a man, but, on the other hand, he had also implied that the natural slave is less than a man. Aquinas tried to solve this contradiction by preserving the theory of natural slavery and redefining the object of its application. As a result, only quasi-humans could be considered natural slaves. Once a being is granted human status, the argument of natural slavery is immediately rendered ineffectual.

Aquinas's conception of history follows Augustine's six stages narrative. His description of the state of innocence, that is, the life of man before the fall from Eden, does not have any allusion to either primitivism or alien cultures (Aquinas 1988). Furthermore, he makes no use of progressive historical accounts to connect the state of innocence to actual societies. 
The task of further exploring the implications of Aquinas's theory of slavery was undertaken by his $16^{\text {th }}$ century Spanish Scholastic followers, who saw themselves under the pressure of the Spanish Crown to evaluate the status of the Indians in the New World. ${ }^{14}$ One of the first theologians to manifest his opinions on this issue was the Dominican Franscisco de Vitoria (1991). ${ }^{15}$ Using second hand knowledge about the life-style and social institutions of the Indians, Vitoria argues that they were rational in potentia but had failed to fully actualize reason. ${ }^{16}$ The solution, thus, would be to lead them to the right path through Christian education. Vitoria proposes that Indians should be "subordinate to [Spaniards], like children to their parents until they reach adulthood, and like a wife to her husband." (Vitoria 1991). Like a child, the Indian was human but not yet fully developed. ${ }^{17}$ Interestingly, however, Vitoria does not explore the possible developmental implications of such 'finding'. He does not present a historical account that would make sense of this developmental gap between Indians and Europeans.

Following Aquinas, Vitoria denies that the natural slave could be a human being. Sharing with his contemporaries an amazement with the news from the New World, Vitoria does not challenge the existence of quasi-human creatures, but he disagrees with the ones who defended that the Indians fit that category. That is, while Vitoria does not frontally deny the potential existence of quasi-human natural slaves, he insists that their actual existence is a matter that could only be confirmed by some sort of ethnological account. His De Indis is rich in second-hand ethnographical information, which he uses to make the case that Indians are indeed fully endowed with rational faculties. In other words, while Vitoria does not challenge the definitional elements of the concept of natural slavery, he questions its applicability and usefulness to the case in hand.

It was the Dominican Thomist Bartolomé de las Casas who started to draw the historical implications of Vitoria's ideas. According to Anthony Pagden, his book Apologética historia (1550) is the first treatise of comparative ethnology written in a European language (Pagden 1982). The main purpose of Las Casas's piece is to prove that all social groups, be they separated by

14 By then, many people related to the Spanish ultramarine colonization were identifying the American Indian with Aristotle's natural slave, thus concluding that they should be lawfully enslaved and dispossessed. The argument is that since they lacked rationality they were not able to pursue their own good, which included having dominium over the lands of the New World.

15 See the lecture De Indis delivered by Vitoria at the Universty of Salamanca in 1539

16 The Spanish Daminican theologians of the Salamanca school, particularly Vitoria, are responsible for the promotion of Aquinas's philosqphy to the first ranks of Catholic doctrine. Aristotle's writings, as well as Aquinas's commentaries on them, were dbligatory items in the program of studies of the Spanish universities.

17 The male child, for Aristotle, perfectly fits the description of the potentially rational creature. 
time or space, share the same underlying social and moral imperatives. Las Casas uses the classical pagan narratives of primitivism to describe human pre-societal life. According to him, barbarism is the starting point of all human societies. He updates the myth by arguing that not only ancient Latins and Celts were barbaric, but also not-so-ancient Germans and British. If those European peoples were once primitive and are now civilized, the Indians could also achieve the same level of civilization. Las Casas devises a stage theory of development that enables him to display the historical paths followed by different societies in parallel. Thus, he concludes, the Roman Empire preceded Christian civilization; the same way the Amerindian Empires preceded Spanish colonization - which eventually will raise them to the highest stage of civilization. Through the inclusion of the category of time (the notion of development in secular history), Las Casas is able to devise an allencompassing comparative ethnology (Pagden 1982). ${ }^{18}$

Las Casas historical conception might be considered universal in the sense that, according to it, all races go through similar stages of civilization and arrive at the same point, which corresponds to the stage achieved by European Christianity. At the same time, his universalism falls short of connecting different peoples from different places and times in a single historical narrative - something that the Enlightenment eventually accomplished. In sum, Las Casas's account is important because it opens the possibility of translating time into space ${ }^{19}$ and vice-versa, even though he does not entirely explores the implications of this "new" possibility.

According to Pagden, it was the Jesuit José de Acosta who composed the first universal moral history of man. While Las Casas's Apologética historia and Argumentum apologiae were not published until his death, Acosta's Historia natural y moral de las Indias was widely received both by religious and non-religious European audiences, from its publication throughout the 1700s. By the end of the $16^{\text {th }}$ century, Jesuits had replaced Dominicans in the leading posts of Spain's theological institutions. They too were Thomists, but with a different attitude. To Dominican scholasticism, the Jesuits added a penchant for practical political disputes, in which they employed theory as a powerful rhetorical instrument (Eisenberg 2000).

According to Acosta, the information that flowed from the New World to Europe was highly unreliable, impairing the capacity that Europeans had to

18 For Las Casas, the lack of synchronous progress between Indians and Europeans should be attributed to environmental and cultural variables - climate was important as well as custams and values. He adds that while the former was not always a problem in the New World the latter was.

19 "Space" here is allturally defined by the habits, lifestyles, and institutions of different peoples perceived as Other. 
judge ultramarine affairs. He argues that a more accurate knowledge of the Indian societies was crucial to the success of the European enterprise, which for the Jesuits included mainly the Christianization of the Indians. Furthermore, studying the Indians would help Europeans understand other non-Christian peoples such as the Chinese, Ethiopians, Calabrians, and so on. Against European prejudices, Acosta affirms that "no man is born without sufficient grace for salvation, neither is any human being, however lowly, incapable of reason, and through the use of reason, of achieving perfection." ${ }^{20}$ Like Vitoria before him, Acosta argued that Indians were like the peasants of Europe; stupid indeed but not incapable of improving their condition through good education. ${ }^{21}$

Even though Acosta claims that the Indians were undeniably barbaric, he also thought the term barbarian was too imprecise as an ethnological tool, and thus in need further qualification. Acosta divided barbarism in three categories, which succeeded each other in an upward progress towards Christian civilization. The most developed stage corresponded to the Asian and Amerindian empires. In the second stage he placed tribal societies and, in the bottom of his classificatory scheme, the men who have no communal life. Each stage of civilization corresponds to a level of linguistic and religious sophistication. Following Aristotle and Aquinas, Acosta considers language to be the most important sign of human rationality. Furthermore, he also claims that the status of the thing worshiped, (i.e, natural elements, animals, and anthropomorphic figures) is further evidence of rational progress.

Acosta explained the lack of synchronic development between different peoples as the product of different historical trajectories. Since, according to him, the human species originated in Europe, the peoples who settled first enjoyed civilized life for a longer period and, therefore, achieved superior rational ways of life. Meanwhile, the peoples who went through long processes of nomadic migrations had little time to develop their rational faculties and tools through civilized life. The Amerindians provide the extreme example. Since Acosta shared with his contemporaries the belief that human beings had originated in Europe, he concluded that Amerindians were still in the childhood of the civilizing process because they were the ones who migrated farther.

Interestingly enough, Acosta is also concerned with determining the end of the world and with matching the dates of secular history to those of sacred history. In fact, for Acosta, the history of human evolution could be unders-

20 Quoted from Pagden 1982, The fall of natural man.

21 Acosta understood that all men are equally rational in potentia, including Africans, who according to him had the most barbarous customs. 
tood as a meaningful narrative not because the end of the world was simply its termination (finis) but because it was the accomplishment (telos) of human moral progress dictated by Divine providence. At the same time, Acosta describes each stage of civilization as being contained in a historical repetitive cycle - a possible borrowing from "classical" notions of history. In a movement that anticipates Hegel's conception of the cunning of history, his solution to this apparent paradox is to argue that a teleological thrust breaks the cycle, compelling men to move to the next stage in an upward movement towards a true Christian society. In sum, while for Acosta, man's history is still what Augustine had called the operatio Dei in time, he thought that the secular evidence of this operation was visible and capable of being organized in a historical narrative with a high degree of coherence.

When faced with the concrete political problem of creating justifications for dealing with the Amerindian populations, the Spanish Thomists seem to have realized that Aquinas's tentative solution for the question of slavery was not entirely satisfactory. After all, Aquinas, who had been transformed by the same theologians in the most important doctrinal authority of the Church, left the door open for speculations about the existence of natural slaves. ${ }^{22}$ Humanists such as Ginés de Sepulveda as well as colonists from Spanish and Portuguese possessions were in fact reviving Aristotle's theory of natural slavery to justify the enslavement of the Amerindians. ${ }^{23}$ Following Aquinas, the Spanish theologians tried to be faithful to both Christian doctrine and Aristotle. Thus, the contradictions of this mixture was once more "solved" by maintaining the Christian rejection of human natural slavery and creating an anthropological theory that could explain human difference without denying the Indians' humanity. Furthermore, this theory provided a fine justification for the policies of the Spanish Crown in the New World.

The anthropological theory of historical development constructed by them allowed for the classification of all human societies. This theory was much more complex and universal than the ancient conception of primitivism which as we saw had a limited ethnological application. More importantly, Acosta's universal history accomplishes the total translation of otherness into primitiveness, that is, the translation of time into space, and vice-versa. Consequently, the Oriental could now be seen as primitive, at the same time that primitive peoples could have Oriental features attributed to them. Acosta and

22 The literature of the New World encounters is full of accounts of quasi-human creatures and monsters. See Gerbi 1973 and Gerbi 1985.

23 Sepulveda used Aristotle theory of natural slavery in the famous debate with Las Casas. See Las Casas, 1552, Aquí se contiene una disputa o controversía, entre el obispo don fray Bartholomé de las Casas o casaus y el doctor Ginés de Sepúlveda. For advocates of the Aristotelian theory in $16^{\text {th }}$ century Brazil see Eisenberg 2000. 
his scholastic precursors not only systematized the notion of historical handicap, they also showed how it could be useful for justifying a Christian colonialist project.

\section{6}

The religious character of history came under severe criticism during the $18^{\text {th }}$ century in France. Authors such as Voltaire, Montesquieu, Condorcet, and Saint-Simon rejected the idea that divine providence manifested itself through human historical progress. Even Turgot, who still saw a correlation between God's will and man's history, also affirmed that history had a "natural law of progress" (Löwith 1949). Voltaire ridiculed sacred history to the point of showing its insignificance to human history (Voltaire 1994). Condorcet, for example, concluded that nature has fixed no limits to human improvement, allowing it to progress indefinitely (Condorcet 1795). One should notice, however, that the dissolution of the religious eschaton, or rather, its transformation into an endless line of improvement, did not considerably alter the perception of other people as historically impaired. On the contrary, with the stress put by the Enlightenment on technical and material progress, the historical gap between peoples became even more palpable. Coherently, Condorcet argued that Orientals live in an infantile state, and together with Africans, will achieve the civilized state only by the hand of the most enlightened and free European nations (Condorcet 1795).

Claiming to have found the first principles from which all particular cases naturally follow and of which the histories of all nations are only consequences, Montesquieu has no place for God's operating will in history. ${ }^{24}$ According to him, the environment was the strongest natural cause behind a people's mores, customs, and laws. From this general rule, he concludes that:

If to that delicacy of organs which renders the eastern nations so susceptible of every impression you add likewise a sort of indolence of mind, naturally connected with that of the body, by means of which they grow incapable of any exertion or effort, it is easy to comprehend that when once the soul has received an impression it cannot change it. This is the reason that the laws, manners, and customs, even those which seem quite indifferent, such as their mode of dress, are the same to this very day in eastern countries as they were a thousand years ago (Montesquieu 1989).

In a truly Hippocratic manner, Montesquieu claims that climate and humidity were the main "Cause of the Immutability of Religion, Manners, Cus- 
toms, and Laws in the Eastern Countries". ${ }^{25}$ The effects of the climate over the human body and mind are so strong that it reduces human beings to a condition similar to Aristotle's natural slaves.

There are countries where the excess of heat enervates the body, and renders men so slothful and dispirited that nothing but the fear of chastisement can oblige them to perform any laborious duty: slavery is there more reconcilable to reason...the master being as lazy with respect to his sovereign as his slave is with regard to him, this adds a political to a civil slavery (Montesquieu 1989).

Montesquieu concludes that no political liberty can exist in warm climates. That maxim applies to Amerindians.

We ought not, then, to be astonished that the effeminacy of the people in hot climates has almost always rendered them slaves; and that the bravery of those in cold climates has enabled them to maintain their liberties. This is an effect which springs from a natural cause... This has also been found true in America; the despotic empires of Mexico and Peru were near the Line, and almost all the little free nations were, and are still, near the Poles (Montesquieu 1989).

Consequently, only Western Europe has a favorable natural setting for free institutions.

The perverse influence of climate could only be partially counteracted by the wisdom of the legislator, but in hot climates even a wise ruler would necessarily be a despot. Like Aristotle before him, Montesquieu 'shows' that despotism is the form of government that suits the Asiatic nature. Nonetheless, he has a keen sense of history that Aristotle lacked. While Aristotle was talking about his contemporaries across the Aegean, Montesquieu was referring to peoples who he thought have been in the same situation for thousands of years. In sum, like Hegel after him, Montesquieu associates Asian despotism with the idea that Asians are historically handicapped. ${ }^{26}$

Contrary to Las Casas and Acosta, who defended that Christian colonization was a necessary and benefic action in dealing with the heathen, Montesquieu expressed profound contempt for the way the Spaniards justified their 'brutal' colonial enterprise in the New World with pious arguments. Despite his acceptance of slavery in countries with warm climates, he was opposed to the colonization of other nations through conquest (Richter 1997). According to Richter, Montesquieu used the image of Asian despotism more as a rhetorical weapon to debate French domestic politics than as an ethnologi-

25 The name of the chapter in the The Spirit of Laws that deals with Eastem Countries. Montesquieu.

26 Hegel cites Montesquieu in the "Introduction" of his Philosgohy of History. 
cal concept. ${ }^{27}$ Nonetheless, what is important here is not Montesquieu's ultimate intentions but the fact that his ethnology let an open door for the justification of colonial practices based on the allegedly incapacity of colonized peoples to be agents of their own history. ${ }^{28}$ In the second era of European colonialism, the notion of historical handicap became an ethnological tool that could be applied to any alien people; be them Indian, African, Asian or else, without the need to justify it in terms of a particular religious theory of history. ${ }^{29}$

Even though the Enlightenment philosophes did not invent the ethnological tool of time-space translation - a device that makes the notion of historical handicap possible - they universalized it by erasing the religious overtones of the ethnological theories concocted by the Spanish Thomists. Now colonialist projects did not have to be justified by a cohesive notion of Christianity. Progress itself, an immanent process of material and moral development, became the European claim to superiority over actual and potential colonies. Through this theoretical movement, Europe explicitly assumed the role of a yardstick against which all other societies must be measured.

Many authors drank from this theoretical fountain. As we have already seen, Hegel's opinion about Orientals echoes Montesquieu's. Marx's ideas on the same subject echo Hegel's. Despite his critique of Hegel's 'idealist' conception of history, Marx follows him almost verbatim when it comes to evaluating the history of the Orient.

Indian society has no history at all, at least knows no history. What we call its history is but the history of the successive invaders who founded their empires on the passive basis of that unresisting and unchanging society (Marx 1853).

The Oriental empires always show an unchanging social infra-structure coupled with unceasing change in the persons and tribes who manage to ascribe to themselves the political superstructure (Marx 1862).

Moreover, Marx's adoption of Hegelian ethnology is coupled with a defense of the benefits of European colonialism.

England has to fulfill a double mission in India: one destructive, the other regenerating - the annihilation of old Asiatic society, and the laying of the material foundation of Western society in Asia (Marx 1853).

27 Richter shows that despotism was a key concept to understanding the political debate that involved the legitimacy of the French monarchy in the $18^{\text {th }}$ century. Both advocates and detractors of monarchical absolutism manipulated the meaning of this conoept to suit their rhetorical purposes. Richter, Melvin, Ibid. 28 Montesquieu's The Spirit of Laws had an ample reception, influencing writers and politicians in France, Germany, the US, and elsewhere.

29 The fracture of Crristian doctrinal unity after more then two hundred years of religious conflicts and wars contributed to undermine the universalism of overtly religious theories of history, such as Acosta's and Las 
Marx shares with Hegel, the philosophes, and the Spanish Thomists the same trust in the universal character of secular historical progress. Aristotle's theory of natural slavery is set aside in the name of ethnological theories that rank societies according to developmental stages. While Aristotle thought that the condition of the natural slave could improve only up to the point of fulfilling his potential as a slave, those authors defended that, at least hypothetically, the colonized could aspire to eventually become full human beings. One has to keep in mind, though, that this humanization would only be accomplished through a painful historical process of both destruction, forced displacement, and education, conduced by the European colonizer.

\section{Conclusion}

The exam of the genealogy of historical handicap shows that this notion has always been put to the service of the freshest intentions of the day, justifying the rule, conquest, and colonization of the Other. It would be naïve, however, to assume an a priori continuity linking the purposes and uses of past anthropological theories. A thinker such as Montesquieu, for example, who "taught" Hegel the principles of historical incapacity, was allegedly against colonialism. The same is probably true in relation to most present-day Latin Americanists, who, in some occasions, have expressed discontent with the most blatantly imperialist policies of the American government ${ }^{30}$. Nonetheless, one should notice that there is an immense gap between an author's intentions in writing and the practices that his theories might help to justify. ${ }^{31}$ That maxim applies for all texts and authors - including Montesquieu and present-day Latin Americanists. In sum, the political analysis of discourse cannot afford to fall in the trappings of authorial intention.

One should notice that, as the Greek example reveals, historical handicap was not the first rhetorical mode used to justify the submission of the Other. Before historical handicap, submission was defended with arguments that despite attesting the ultimate inferiority of barbaric lifestyles, had no temporal import. At the same time, Greek theories of primitivism, which encased conceptions of history, did not seem to have served the same practical

Casas'. The Enlighterment, thus, provided the perfect solution for unifying the European claim to superiority in the allegedly non-religious terms of civilization and progress.

30 Some Latin American scholars have being active in defending the compliance of American foreign policy to human rights standards. Many Latin Americanists overtly rejected Reagan's policies toward Nicaragua and El Salvador in the 1980s. See Schoultz 1980 and Schoultz 1998.

31 For a mild but very insightful criticism of the idea of authorial intention, see Ricoeur 1981. A stronger criticism can be fand in Bardieu 1991. For a total rejection of the idea of authorial intention see Foucault 1972 and Barthes 1979. 
purposes. The notion of historical handicap originally appeared in sixteenth century as an attempt to interpret the Amerindians' case according to the Thomist theory of slavery. This intellectual effort originated new developmental stage-theories that incorporated elements from classical primitivism and the Christian notion of teleological history. Such theories allowed for the translation of cultural difference into temporal difference - the basic structural element of historical handicap. On the practical side, they justified the European right to colonize the New World. In the modern era, the notion of historical handicap was employed and perfected by prominent authors of the Western philosophical tradition, and became the most powerful rhetorical instrument to justify the submission of the Other. It has served European colonialist adventures in Asia, Africa, and America, and nowadays it is fully operative in texts on Latin America produced by American social scientists. Would these texts also be rhetorical instruments for justifying the submission of a Latin American Other?

The answer seems to be affirmative. Some authors have showed that the theories of development produced by American social scientists have often served to justify political and economic intervention in the 'Third World' in general (Gendzier 1985), and particularly in "Latin America" (Berger 1995, Escobar, 1995 \#3101). Those critics claim that social scientific discourse has served as a form of colonialist ideology. If that is true, it would be useful to examine in detail the ways in which Latin America is conceptualized by American social scientists as a "place in a different time", that is, as a historically handicapped "society". We must examine Latin America studies as a form of ethnology and question its most basic conceptions. What constitutes the Latin character of Latin America? What makes Latin America a meaningful unity? Under which conditions Latin America is constructed as an object for social scientific discourse? What kind of knowledge has been produced by this social scientific enterprise? The answer to these questions will be pursued in a future opportunity.

\section{References}

Aquinas, Thomas. 1988. St. Thomas Aquinas on Ethics and Politics. New York: W.W. Norton \& Company.

Aristotle. 1958. The Politics of Aristotle. New York: Oxford University Press. Augustine, Saint. 1958. City of God. New York: Image Books.

Berger, Mark T. 1995. Under Northern eyes : Latin American studies and U.S. hegemony in the Americas, 1898-1990. Bloomington: Indiana University Press.

Blumenberg, Hans. 1974. "On a Lineage of the Idea of Progress" in Social Research,41: 5-27. 
Condorcet, Marie-Jean-Antoine-Nicolas de Caritat marquis de. [1795] 1988. Esquisse d'un tableau historique des progrès de l'esprit humain. Paris: Flammarion.

Dealy, Glen Caudill. 1996. "Two cultures and political behavior in Latin America" in Democracy in Latin America: Patterns and Cycles. ed. R. A. Camp. Wilmington: Scholarly Resources Inc.

Eisenberg, José. 2000. As missões jesuíticas e o pensamento político moderno; encontros culturais, aventuras teóricas. Belo Horizonte: Editora da UFMG.

Gendzier, Irene L. 1985. Managing political change: social scientists and the Third World. Boulder: Westview Press.

Gerbi, Antonello. 1973. The dispute of the New World; the history of a polemic, 1750-1900. Pittsburgh: University of Pittsburgh Press.

Gerbi, Antonello. 1985. Nature in the New World; from Christopher Columbus to Gonzalo Ferández de Oviedo. Pittsburgh: University of Pittsburgh Press.

Hegel, Georg Wilhelm Friedrich. 1899. The philosophy of history. New York: The Colonial Press.

Las Casas, Bartolomé de. 1552. Aquí se contiene una disputa o controversía, entre el Obispo don fray Bartholomé de las Casas o Casaus y el doctor Ginés de Sepúlveda. Seville.

Lipset, Seymour Martin, and Aldo E. Solari. 1967. Elites in Latin America. New York: Oxford University Press.

Lovejoy, Arthur O., and George Boas. 1935. Primitivism and related ideas in antiquity. Baltimore and London: John Hopkins University Press.

Löwith, Karl. 1949. Meaning in history. Chicago and London: Phoenix Books, The University of Chicago Press.

Marx, Karl. 1853. "The Future Results of British Rule in India" in NYDT,August 8:

Marx, Karl. 1862. "Discussing the Taiping Rebellion" in Vienna Die Presse, July 7:

Montesquieu, Charles de Secondat, baron de. 1989. The spirit of laws. Cambridge; New York: Cambridge University Press.

Pagden, Anthony. 1982. The fall of natural man : the American Indian and the origins of comparative ethnology. Cambridge, New York: Cambridge University Press.

Richter, Melvin. 1990. "Aristotle and the classical Greek concept of despotism" in History of European Ideas, 12: 2: 175-187.

Richter, Melvin. 1997. "Europe and The Other in Eighteenth-Century Thought" in Politisches Denken, Jahrbuch: 25-47.

Schoultz, Lars. 1980. "US Diplomacy and Human Rights in Latin America" in Latin America, the United States and the Inter-American System. ed. L. Schoultz. Boulder: Westview Press.

Schoultz, Lars. 1998. Beneath the United States: a history of US policy toward Latin America. London and Cambridge: Harvard University Press.

Smith, Christian. 1994. "The spirit and democracy: base communities, Protestantism, and democratization in Latin America" in Sociology of Religion, 55: 2, Summer: 119-43.

Vitoria, Francisco de. 1991. Political writings. Cambridge; New York: Cambridge University Press. 
Voltaire. 1994. Political writings. Cambridge; New York: Cambridge University Press. Wiarda, Howard J. 1990. The democratic revolution in Latin America. New York: Holmes and Meier, for the Twentieth Century Fund.

31-22 41st Street 1st fl. Astoria NY 11103 USA iferes@att.net 